\title{
Climate-smart cropping systems for temperate and tropical agriculture: mitigation, adaptation and trade-offs
}

\author{
Philippe Debaeke ${ }^{1, *}$, Sylvain Pellerin ${ }^{2}$ and Eric Scopel ${ }^{3}$ \\ ${ }^{1}$ Inra, UMR AGIR, 31326 Castanet-Tolosan, France \\ 2 Inra, UMR ISPA, 33883 Villenave-d'Ornon, France \\ ${ }^{3}$ CIRAD, UPR AIDA, 34398 Montpellier, France
}

\begin{abstract}
Climate-smart cropping systems should be designed with three objectives: reducing greenhouse gas (GHG) emissions, adapting to changing and fluctuating climate and environment, and securing food production sustainably. Agriculture can improve the net GHG emissions balance via three levers: less $\mathrm{N}_{2} \mathrm{O}, \mathrm{CH}_{4}$ and $\mathrm{CO}_{2}$ emissions, more carbon storage, and green energy production (agrifuels, biogas). Reducing the application of mineral $\mathrm{N}$ fertilizer is the main option for reducing $\mathrm{N}_{2} \mathrm{O}$ emissions either directly or by increasing the proportion of legumes in the rotation. The most promising options for mitigating $\mathrm{CH}_{4}$ emissions in paddy fields are based on mid-season drainage or intermittent irrigation. The second option is storing more carbon in soil and biomass by promoting no-tillage (less fuel, crop residues), sowing cover crops, introducing or maintaining grasslands and promoting agroforestry. Breeding for varieties better adapted to thermal shocks and drought is mainly suggested as long-term adaptation to climate change. Short-term strategies have been identified from current practices to take advantage of more favorable growing conditions or to offset negative impacts: shifting sowing dates, changing species, cultivars and crop rotations, modifying soil management and fertilization, introducing or expanding irrigation. Some crops could also move to more suitable locations. Model-based tools and site-specific technologies should be developed to optimize, support and secure farmer's decisions in a context of uncertainty and hazards. Most of the adaptation and mitigation options are going in the same way but tradeoffs will have to be addressed (e.g. increasing the part of legumes will be possible only with significant breeding efforts). This will be a challenge for designing cropping systems in a multifunctional perspective.
\end{abstract}

Keywords: climate change / adaptation / mitigation / trade-offs / conservation agriculture

\begin{abstract}
Résumé - Des systèmes de culture climato-intelligents pour les agricultures tempérées et tropicales : atténuation, adaptation et compromis. Des systèmes de culture climato-intelligents doivent combiner (i) réduction des émissions de gaz à effet de serre (GES), (ii) adaptation au changement et à la variabilité climatique et (iii) sécurisation de la production alimentaire. L'agriculture peut améliorer le bilan des émissions de GES via trois leviers: (i) moins d'émissions de $\mathrm{N}_{2} \mathrm{O}, \mathrm{CH}_{4}$ et $\mathrm{CO}_{2}$, (ii) plus de stockage du carbone, (iii) de la production d'énergie verte (biocarburants, biogaz). Réduire l'application d'engrais minéral ou augmenter la proportion de légumineuses dans la rotation permet de réduire les émissions de $\mathrm{N}_{2} \mathrm{O}$. La réduction des émissions de $\mathrm{CH}_{4}$ en riziculture inondée impose de revoir la gestion de l'eau (drainage, irrigation). Stocker plus de carbone dans le sol et la biomasse passe par la culture sans labour (moins d'énergie, paillage avec les résidus de récolte), l'utilisation de plantes de couverture, l'introduction ou le maintien de prairies et la pratique de l'agroforesterie. La sélection de variétés mieux adaptées aux chocs thermiques et à la sécheresse est la principale adaptation à long terme au changement climatique. Des stratégies à court terme ont été identifiées à partir des pratiques actuelles, tirant profit de conditions de croissance plus favorables ou compensant les impacts négatifs par le décalage des dates de semis, l'introduction de nouvelles espèces et cultivars, la diversification des rotations, de nouvelles pratiques de gestion du sol et de la fertilisation, l'introduction ou l'expansion de l'irrigation. Certaines cultures pourraient également migrer vers des zones de culture plus appropriées. Des outils basés sur les modèles et l'agriculture de précision devraient être développés afin d'aider les agriculteurs face à un contexte plus incertain et plus
\end{abstract}

\footnotetext{
* Corresponding author: philippe.debaeke@inra.fr
} 
risqué. La plupart des options d'adaptation et d'atténuation sont compatibles, mais des arbitrages devront être faits : ainsi augmenter la part des légumineuses ne sera possible que si des efforts de sélection importants sont conduits.

Mots clés : changement climatique / adaptation / atténuation / antagonismes / agriculture de conservation

\section{Introduction}

Climate change, particularly increasing temperatures, altered rainfall patterns, and climate variability (including extreme climate events) will affect dramatically the productivity of crops and their regional distribution in the next decades with severe impacts on food security (Porter et al., 2014). However, despite common trends, regional and local differences are expected.

Sub-Saharan Africa is thought to be the region most vulnerable to these impacts (Challinor et al., 2007). The onset and length of growing seasons governed by rainfall patterns should be deeply modified by 2050 (Sarr, 2012) and crop yields could decrease by $6-24 \%$ depending on climate scenario and management strategy (Waha et al., 2013).

In Europe, grain yield stagnation and increased yield variability in cereals have been related to recent changes, and especially to increasing heat stress during grain filling (e.g. for wheat, Brisson et al., 2010). Future projected trends include (i) new opportunities due to the northward movement of crop suitability zones and increasing crop productivity in Northern Europe, but (ii) negative impacts in southern parts where climatic risks will intensify while productivity and suitability will decline (Moriondo et al., 2010; Donatelli et al., 2012; Iglesias et al., 2012; Supit et al., 2012). This may be accompanied by a widening of water resource differences between the North and South, and a general increase in extreme rainfall events and droughts (Falloon and Betts, 2010).

Climate change will impact crop production directly or not (Fig. 1). Changes of atmospheric $\mathrm{CO}_{2}$ concentration, of mean and extreme temperatures, and of rainfall amount and timing will directly affect yields and land use (crop suitability). It will also result in changes in water availability patterns and in additional irrigation requirements that will subsequently affect agricultural productivity (Anwar et al., 2013). In addition, emergent pests and diseases may result in dramatic crop damages (Gregory et al., 2009).

Being partly responsible of the emissions of greenhouse gases (GHG), world agriculture has to reduce its carbon footprint while increasing biomass production to match the needs of a growing population (Smith et al., 2014). In a perspective of climate-smart agriculture (CSA), a variety of innovative crop production systems should be designed and spatially arranged, with three objectives: (i) reducing GHG emissions and storing more carbon in soils and biomass, (ii) coping with changing and fluctuating environments to reduce the vulnerability of agricultural systems, and (iii) securing food production both in quantity, quality and diversity (FAO, 2013; Lipper et al., 2014; Torquebiau, 2015). A wide range of candidate options have been proposed for these multiple goals in relation to public policy, markets, education and training, advisory systems, climate forecasting, plant breeding and cropping systems changes.
Cropping systems are currently defined as the cultural practices applied to crop sequences at field level. More generally the cropping system concept is used when qualifying and managing land use at the territorial level (Boiffin et al., 2014). Cropping systems offer a diversity of options that can be combined to build climate-smart agriculture together with genetics, machinery and information technology. As cropping systems are both levers for adaptation and mitigation and impact food production, multiple trade-offs between cropping systems options have to be identified in a perspective of global optimization of crop production systems (Rosenzweig and Tubiello, 2007).

Numerous studies have reported positive or negative impacts of agriculture on GHG emissions (Pellerin et al., 2013). Until recently, studies addressing the vulnerability of crops to climate change were focusing on climate impact without considering explicitly adaptation. However, the number of papers addressing adaptation has increased exponentially in the last years. According to the Web of Science, $75 \%$ of the papers mentioning "adaptation + climate change + agriculture or farm or crop" as topics (on a total of 6100) were published since 2011.

In this paper, we present and discuss cropping systems options to reduce GHG emissions and store more $\mathrm{C}$ and to contribute to the adaptation of agriculture to climate change (i.e. reducing the vulnerability of crop production, increasing resilience and resource-use efficiency). Then we will identify necessary trade-offs to deal with in the context of climatesmart agriculture.

\section{Reducing greenhouse gases emissions by modifying cropping systems}

The agriculture, forestry and other land use (AFOLU) sector is responsible for $24 \%\left(10-12 \mathrm{Pg} \mathrm{CO}_{2}\right.$ per year) of greenhouse gases emissions worldwide, with concomitant opportunities for mitigation (Smith et al., 2014). A specific feature of agricultural emissions is that they are mostly non energy-related and controlled by biological processes. Agriculture can help improve the net GHG emissions balance via three levers: a reduction in $\mathrm{N}_{2} \mathrm{O}$ and $\mathrm{CH}_{4}$ emissions (and also $\mathrm{CO}_{2}$ emissions due to soil $\mathrm{C}$ mineralization and fossil fuel consumption by machinery), additional carbon storage in soils and biomass, and energy production (e.g. agrifuels, biogas) to replace fossil energies. Bioenergy production by the agricultural sector poses specific challenges and questions, which have been addressed by many authors (see for instance Gabrielle et al., 2014). In this paper, we will focus on the first two levers for mitigation (Tab. 1).

The current typology for adaptation to climate change and adoption of mitigation measures in the agriculture sector considers (i) incremental changes and autonomous farmer's responses (e.g., shifting the planting date, switching crop varieties, including annual legumes) and (ii) planned and 


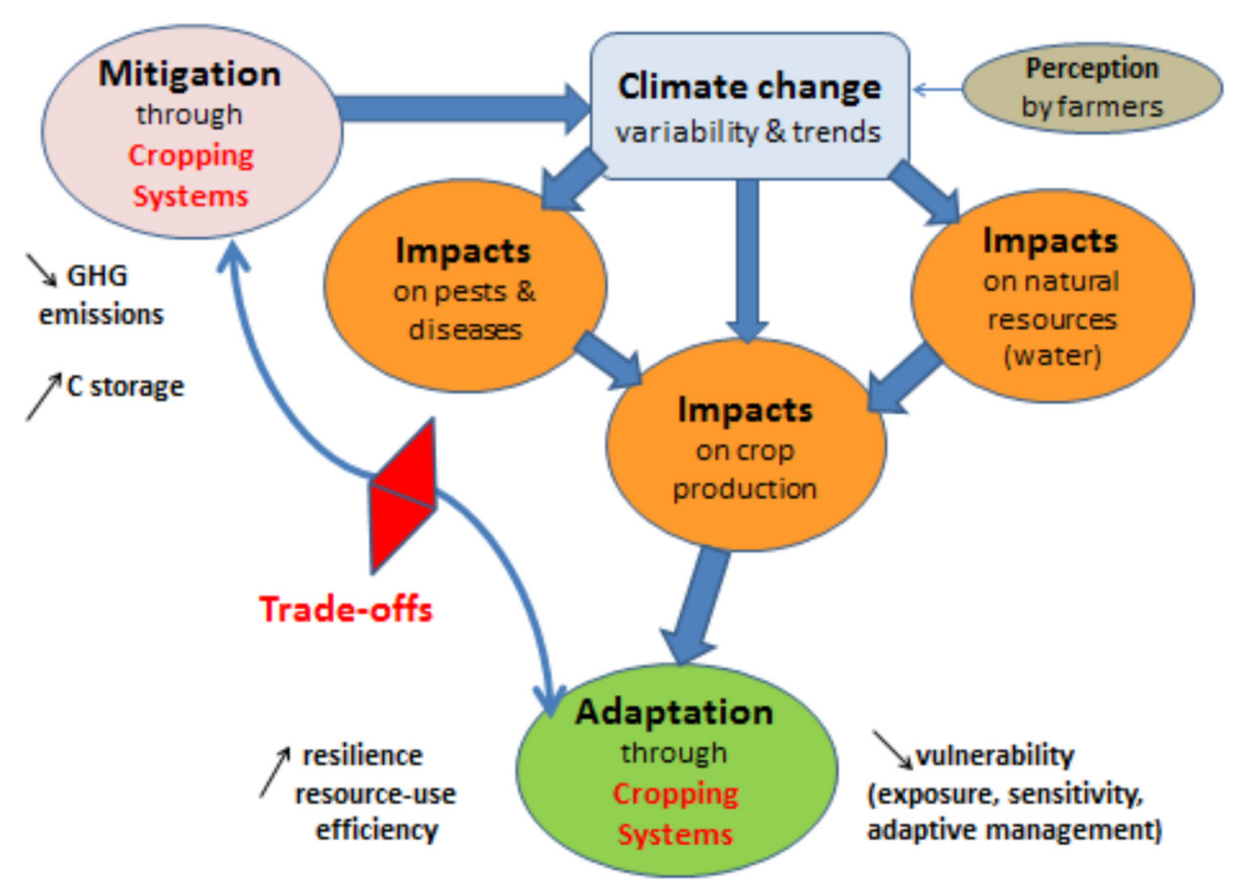

Fig. 1. A schematic representation of the main components of climate change problems and the way cropping systems could influence both adaptation and mitigation.

Fig. 1. Principales composantes du changement climatique en agriculture et voies par lesquelles les systèmes de culture peuvent influer l'adaptation au changement climatique et l'atténuation des émissions de gaz à effet de serre.

Table 1. Some agricultural practices have been assessed for their performance in reducing nitrous oxides, methane and $\mathrm{CO}_{2}$ emissions and storing $\mathrm{C}$ in soils or biomass ; main options are considered here, in a qualitative way. $\mathrm{N}_{2} \mathrm{O}$ can be reduced by more legumes in crop rotations and a better adjustment of $\mathrm{N}$ fertilization; $\mathrm{C}$ storage can be increased by no-till, residue management, introduction of cover crops, and more trees in agrosystems (from Pellerin et al., 2014).

Tableau 1. Certaines pratiques agricoles ont été évaluées quant à leur capacité à réduire les émissions de protoxyde d'azote ( $\left.N_{2} 0\right)$, de méthane $\left(\mathrm{CH}_{4}\right)$ et de gaz carbonique $\left(\mathrm{CO}_{2}\right)$ et à stocker du carbone dans les sols et la biomasse; les principales options sont considérées ici. Les émissions de $\mathrm{N}_{2} \mathrm{O}$ peuvent être réduites par une plus forte introduction de légumineuses dans la rotation et par un ajustement de la fertilisation azotée; le stockage du carbone peut augmenter via le non-travail du sol, la gestion des résidus de culture, l'introduction de cultures intermédiaires, et la plantation d'arbres dans les agrosystèmes (d'après Pellerin et al., 2014).

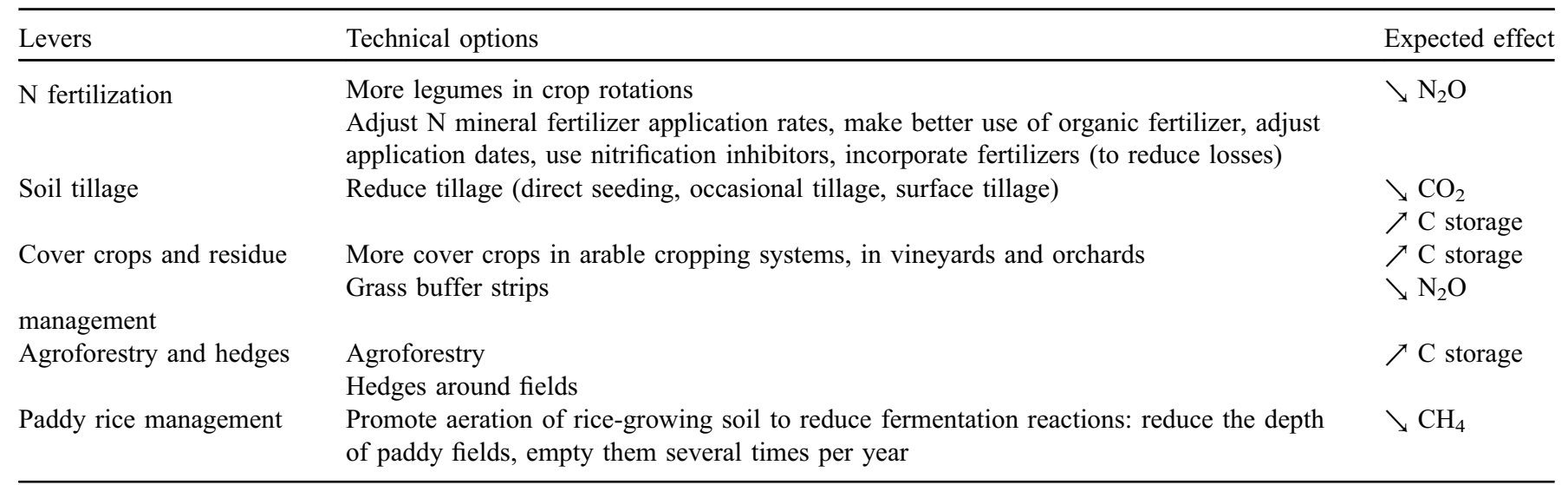

transformational changes that require substantial investment (e.g. development of new crop varieties, expanding irrigation infrastructure, introducing agroforestry) (Stokes and Howden, 2010). Autonomous adjustments include farmer's efforts to optimize production without major system changes and without the implication of other sectors (e.g. public policy, research). Transformational adaptations are those that are adopted at a much larger scale, that are truly new to a particular region or resource system, and that transform places and shift locations (Kates et al., 2012). They refer to major structural changes to overcome adversity caused by climate change. Another distinction is to consider short-term, medium-term 
and long-term adaptations, the first one being generally autonomous and the others being more organized and planned by the agricultural sector and policy makers.

\subsection{Reduce $\mathrm{N}_{2} \mathrm{O}$ and $\mathrm{CH}_{4}$ emissions from agricultural soils}

Nitrous oxide $\left(\mathrm{N}_{2} \mathrm{O}\right)$ is produced during biochemical denitrification and nitrification reactions occurring in soils or during manure storage. Although many factors control $\mathrm{N}_{2} \mathrm{O}$ production and diffusion in soils (aeration, temperature, $\mathrm{pH} . .$. ), annual emissions are highly determined by the amount of $\mathrm{N}$ supplied by mineral and organic fertilizers since $\mathrm{N}_{2} \mathrm{O}$ production strongly depends on nitrate and ammonium concentrations in soils. In intensively fertilized cropping systems, reducing the application of mineral $\mathrm{N}$ fertilizers is the main option for reducing $\mathrm{N}_{2} \mathrm{O}$ emissions. This can be achieved without reducing yields by (i) strictly adjusting $\mathrm{N}$ fertilizer rates to crop requirements; (ii) taking into account all $\mathrm{N}$ sources in the $\mathrm{N}$ budget calculation, especially organic products like manures and crop residues whose contribution to $\mathrm{N}$ supply is often under-estimated and (iii) improving the efficiency of $\mathrm{N}$ supply by splitting fertilizer application in time, and incorporating and localizing fertilizers to avoid losses, especially by ammonia volatilization during spreading, and increase root uptake. Calculating a provisional $\mathrm{N}$ budget for an accurate estimation of fertilizers needs remains challenging (Ravier et al., 2016), especially in a context of increasing climatic variability, but $\mathrm{N}$ fertilizer supply can be readjusted during crop growth thanks to plant-based diagnostic tools (Lemaire et al., 2008; Ziadi et al., 2010; Gianquinto et al., 2011; Jeuffroy et al., 2013a). Application of nitrification inhibitors is an additional option, but its cost is much higher than the cost of measures based on better adjustment of $\mathrm{N}$ fertilization rates (Pellerin et al., 2014). A second lever to reduce $\mathrm{N}_{2} \mathrm{O}$ emissions is to increase the proportion of $\mathrm{N}$ fixing legumes in crop rotations, either as main crops (including temporary grasslands) or as cover crops between two cash crops. Recent studies have shown that $\mathrm{N}$ fixation by legumes is not an $\mathrm{N}_{2} \mathrm{O}$ emitting process (Rochette and Janzen, 2005), whereas high concentrations of nitrates and/or ammonium in soils following fertilizer applications are responsible for $\mathrm{N}_{2} \mathrm{O}$ emission peaks. Legumes do not require any $\mathrm{N}$ application, and their N-rich crop residues can supply $\mathrm{N}$ to the following crop. All these measures reducing mineral $\mathrm{N}$ application rates, reduce direct $\mathrm{N}_{2} \mathrm{O}$ emissions occurring on fields (Jeuffroy et al., 2013b) and indirect emissions occurring downstream after lixiviation of nitrate or volatilization of ammonia. Moreover, they reduce emissions occurring upstream since the manufacture of synthetic nitrogen fertilizers requires large quantities of energy. A better $\mathrm{N}$ management in cropping systems is also likely to have positive side-effects on other agrienvironmental issues like water quality (less nitrate leaching), air quality (less ammonia volatilization) and preservation of biodiversity (less $\mathrm{N}$ deposition on natural ecosystems).

Methane $\left(\mathrm{CH}_{4}\right)$ is produced during fermentation of organic matter under anaerobic conditions. Worldwide, $27 \%$ of anthropogenic $\mathrm{CH}_{4}$ emissions are due to enteric fermentation by ruminants, $23 \%$ to landfills and waste management, $11 \%$ to rice production and $39 \%$ to biomass and fossil fuels burning
(Ciais et al., 2013). In well-aerated cropland, soils net $\mathrm{CH}_{4}$ emissions are usually very low, so that mitigation options in agriculture mainly concern paddy rice cropping systems. The most promising options for mitigating $\mathrm{CH}_{4}$ emissions in paddy fields without reducing yields are based on water management (Yan et al., 2009; Fumoto et al., 2010). Compared to continuous flooding, mid-season drainage or intermittent irrigation effectively curtail methane emissions (Towprayoon et al., 2005; Khosa et al. 2011). Although draining continuously flooded rice fields may lead to an increase in $\mathrm{N}_{2} \mathrm{O}$ emission, the global warming potential resulting from this increase is negligible when compared to the reduction in global warming potential that would result from the $\mathrm{CH}_{4}$ reduction associated with draining the fields (Yan et al., 2009). However, such mitigation practice is only feasible where complete control of water supply and drainage is possible, which is not always the case, especially during rainy seasons. Other mitigation levers are related to the choice of the rice cultivar (varieties with low gas transport capacities and low exudate formation), crop residue management (incorporating organic material in the dry period rather than in flooded periods) and fertilizer management practices (Majumdar, 2003; Xie et al., 2010; Linquist et al., 2012). Since water, carbon and nitrogen dynamics are closely interrelated, the use of process-based biogeochemical models is increasingly needed to explore and assess mitigation strategies for paddy rice cropping systems in the tropics (Chun et al., 2016).

\subsection{Increase carbon storage in soils and biomass}

Soil carbon stock reflects the long-term equilibrium between carbon inputs (rhizodeposition, crop residues and exogenous organic products) and carbon losses by mineralization. Increasing carbon stocks in soils has been considered as a promising option for mitigating climatic change for decades (Arrouays et al., 2002; Lal, 2011). Increasing C stocks in agricultural soils can be achieved by reducing the $\mathrm{C}$ mineralization rate, increasing $\mathrm{C}$ input and combining both levers. Reduced tillage has often been considered as a management practice fostering $\mathrm{C}$ storage by reducing mineralization rate. Recent meta-analysis of long-term experiments confirmed this trend, although to a lesser extent than initially thought (Angers and Eriksen-Hamel, 2008; Dimassi et al., 2013; Powlson et al., 2014). Additional C storage under reduced tillage is not always observed. It does not occur or is even lowered if biomass production (and therefore $\mathrm{C}$ input by crop residues) is also reduced (Virto et al., 2012). The effect of reduced tillage on carbon stocks also depends on climatic conditions, with less additional $\mathrm{C}$ storage under wet climate since mineralization of crop residues remaining on soil surface is favored (Dimassi et al., 2014). Moreover, no-till may increase $\mathrm{N}_{2} \mathrm{O}$ emissions in poorly-aerated soils (Rochette, 2008), so that all GHG sources should be considered when assessing reduced tillage as a mitigation option (higher $\mathrm{C}$ storage in soil if any, less $\mathrm{CO}_{2}$ emissions by tractors, possible effect on $\mathrm{N}_{2} \mathrm{O}$ emissions). Therefore, the identification of soil, climate and agronomical conditions under which reduced tillage can improve the overall GHG budget of cropping systems remains an important challenge for future agronomical research. Increasing $\mathrm{C}$ inputs can be achieved by recycling 
Table 2. Technical options that could be combined to reduce the vulnerability of cropping systems and take advantage of new cropping opportunities. Different strategies can be applied concerning water and heat stresses: escape, avoidance (via crop rationing), tolerance, attenuation, resource conservation, resilience (recovery).

Tableau 2. Options techniques qui pourraient être combinées pour réduire la vulnérabilité des systèmes de culture et tirer parti des opportunités offertes par le changement climatique. Plusieurs stratégies peuvent être mises en ouvre pour faire face aux stress hydriques et thermiques : l'esquive, l'évitement (via le rationnement végétatif), la tolérance, l'atténuation, la conservation des ressources, la résilience (récupération).

Levers Technical options

Crop species \& varieties

(stress escape) more appropriate thermal time and vernalization requirements

(stress tolerance) increased tolerance to heat shock, drought, waterlogging, low temperature, emergent pests and diseases...

$\begin{array}{ll}\text { Crop management } & \text { (stress avoidance) lower water needs, optimal water use pattern } \\ \text { (escape) shifting sowing date to escape water and thermal stresses }\end{array}$ (avoidance) nutrient applications, planting density and spatial arrangements (e.g. skip row) adjusted to precipitation patterns and yield goals (attenuation) supplementary/deficit irrigation if available (conservation) soil tillage and residue management to maximize soil water storage, reduce evaporation, runoff and erosion

Cropping pattern Diversify crops and cultivars to increase resilience (rotation, landscape); variety mixtures and intercropping; agroforestry; flexible systems; double and relay cropping

Information and decision system Use seasonal weather forecasting; model-based decision support systems (DSS)

more organic products (but most of them, especially manure, are already recycled) or by increasing field biomass production and recycling (crop residue incorporation, cover crops between cash crops, cover cropping in vineyards and orchards). Although a large part of the additional biomass is readily mineralized after incorporation in soils, recent studies of longterm experiments have confirmed a positive effect on soil $\mathrm{C}$ stocks (Justes et al., 2012; Autret et al., 2016).

Additional $\mathrm{C}$ storage in biomass without reducing yields may be obtained by developing agroforestry with a low tree density and planting hedges around fields. These measures also increase soil $\mathrm{C}$ stocks by increasing $\mathrm{C}$ inputs (leaves, roots). The abatement potential of agroforestry and hedges in temperate and tropical contexts has been highlighted in several studies at national and continental scale (e.g. Aertsens et al., 2013 for the European Union). Several technical constraints are likely to limit the applicability of these measures as they cannot be used on small fields that limit machinery use, and cannot be applied to shallow soils or soils with low water holding capacity to avoid water competition with crops. Moreover, additional labor time is required from farmers for tree and hedge maintenance, thus limiting adoption. Even considering these constraints, a national study carried out for France highlighted the high mitigation potential of agroforestry at a moderate cost since additional labor costs are partially offset by economic outlets for additional products like wood (Pellerin et al., 2014).

Most of the previously mentioned management practices promoting $\mathrm{C}$ storage in soils and biomass have several positive and a few negative side-effects related to other agri-environmental issues. Weed control may become more complicated with no or reduced tillage, thus increasing the use of herbicides. Using occasional tillage to solve severe weed problems should minimize the negative aspect of continuous no tillage on herbicide use. Besides increasing soil C stocks, cover crops limit $\mathrm{N}$ losses by leaching during the intercrop period and may provide $\mathrm{N}$ to the next crop, thus reducing $\mathrm{N}$ fertilizer needs and $\mathrm{N}_{2} \mathrm{O}$ emissions (Justes et al., 2012). They also reduce erosion risks in susceptible croplands. Antagonisms may appear with water management under dry climate because of water consumption by cover crops, so that interactions between $\mathrm{C}, \mathrm{N}$ and water cycles should be considered. Besides its mitigation effect, higher carbon content in soils increases soil structural stability, limits erosion risks, increases water infiltration and holding capacity, and improves soil fertility. Trees and hedges in agricultural landscapes provide habitats for wildlife and may help reducing the use of pesticides by favoring biodiversity and biological regulation of pests.

\section{Adaptation of cropping systems to changing climate and fluctuating environments}

\subsection{Short-term risk management at farm level}

Adjustments in production technology, crop management and cropping system composition to adapt to climate change at farm level in an autonomous way have been extensively reported in the literature (e.g. Smit and Skinner, 2002; Howden et al., 2007; Olesen et al., 2007; Olesen et al., 2011; Anwar et al., 2013). Numerous local and regional studies (field experiments, participatory approaches, modelling exercises) have been conducted to define the best management options to cope with on-going climate variability and future climate scenarios at different time horizons.

We identified a range of short-term strategies based on current practices, either to take advantage of more favorable growing conditions or to offset negative impacts due to the changing duration of growing seasons, and the increased occurrence of droughts and heat waves (Tab. 2).

\subsubsection{Shifting planting dates}

Shifting planting dates to face new temperature and precipitation patterns is the simplest and low-cost adaptation 
strategy. Therefore, it is one of the most reported among climate change studies either in Europe, Asia or Africa (e.g. Brisson and Levrault, 2010; Chen et al., 2012; Jalota et al., 2012; Laux et al., 2010; Waha et al., 2013; Waongo et al., 2015). For instance, in Europe, earlier sowing of spring crops (e.g. sugar beet, maize) is recommended to take advantage of the longer growing season at higher latitudes. In southern conditions where water stress and high temperatures are expected in summer, anticipating planting and using earlymaturing varieties jointly could be an efficient drought escaping strategy for spring-planted crops (Moradi et al., 2013). In the North China Plain for instance, a "double-delay" technology was suggested which consists in delaying both the sowing time of wheat in autumn and the harvesting time of maize, leading to an overall 4-6\% increase in total grain yield of the wheat-maize system with climate change (Wang et al., 2012). In the Loess Plateau of China and similar semiarid environments, the wheat sowing date could be delayed by 10 to 20 days in the wet and medium years, and by 20 to 25 days in the dry years compared with the current sowing date (20 September) in order to better adjust the soil water condition to phenological development (Ding et al., 2016). In some Mediterranean regions, it was even suggested to plant sunflower crop in late autumn or winter (instead of spring as usually) to escape water stress at flowering and during grain filling, with good results in water use efficiency and yield (Soriano et al., 2004).

\subsubsection{Choosing and including new crops and cultivars}

Changing crop species and cultivars to take advantage of opportunities offered by climate change or to minimize the vulnerability to extreme conditions is an additional strategy that should be combined consistently with the change of planting date.

The shorter crop duration with increasing temperature could be compensated for by using long cycle cultivars combined with early sowing dates. This will extend the radiation interception period. Varieties and species with thermal time and vernalization requirements in line with specific characteristics of the growing seasons should be sown preferably.

In the conditions where escaping and avoiding strategies are not applicable, where water resources are scarce and the likelihood of high temperatures increases during the most susceptible phenological phases, varieties and species with increased resistance to heat shocks and drought could be preferred when available. For instance, earlier flowering varieties could be adopted to allow grain filling to occur in the cooler and wetter parts of the year (van Ittersum et al., 2003; Debaeke, 2004). The substitution of irrigated maize by moderately irrigated or rainfed crops (e.g. sunflower, sorghum) or fall-planted crops could be recommended to face the increasing water problems in western and southern Europe (Debaeke et al., 2008).

\subsubsection{Modifying and widening crop rotations}

Crop diversification (at field, farm or territory level) could be widened as a self-insurance measure to cope with more uncertain, infrequent and fluctuant climatic conditions, pest and disease infestations and price context (Bradshaw et al., 2004). The introduction of additional intra- and inter-specific planned biodiversity at field and farm level and in time (crop rotations) is expected to bring more resilience to the production system under climate variability and change. Running simulations for the second half of the century using the A1B scenario of the IPCC (2007), Nendel et al. (2014) designed crop rotations that are expected to become possible in the future in Germany due to a prolonged vegetation period and at the same time shortened cereal growth period: for instance, spring barley succeeding to winter barley could likely be successful but no more (late-sown) winter wheat after sugar beet because of drought exposure. The intensification of the cropping cycle by double cropping could benefit from the longer growing season and allow for larger annual yields in spite of climate change (Graß et al., 2015; Seifert and Lobell, 2015). Very early-maturing varieties could be planted after winter crops which complete their cycle in late spring. However, irrigation may become required for double crop establishment whereas water availability could be restricted in summer in some areas. If climate change also results into impacts on river flows and groundwater resources, the incorporation of double cropping could be constrained by imbalances between water demand and supply. In Sub-Saharan Africa, sequential cropping systems (including double cropping) is also reported as a way to maintain overall crop production, provided farmers adapt the sowing dates to the changing climatic conditions (Waha et al., 2013).

In the next decades, the cropping landscape will be probably partly modified with climate change and some crops and cropping systems will migrate to more suitable locations. In Europe, heat-requiring crops will move towards northern regions (Tuck et al., 2006) with the expansion of climatically suitable areas. This should bring new opportunities for diversifying winter-based crop rotations.

\subsubsection{Increasing water availability and water use efficiency by irrigation, crop management and cropping systems}

Supplemental or deficit irrigation (either expanded or introduced) is an effective way to maintain or increase grain yield in dry conditions, but future water resources could be limited because of competition among users, especially in the Mediterranean area. Extra precipitation in winter could however be stored for securing summer irrigation when possible. The need for water security will be greatest in Southern Europe as a result of increased production vulnerability, reduced water supply and increased demands for irrigation (Doll, 2002; Brisson and Levrault, 2010; Falloon and Betts, 2010; Zhao et al., 2015). For instance, irrigation is projected to considerably improve and stabilize the yields of late-maturing cereals and of shallow rooting crops (maize and pea) on sandy soils under the continental climate of Germany (Nendel et al., 2014).

It has been often reported that crop management still offers a range of opportunities - that could be optimized - to cope with drought-prone conditions and changing climate in rainfed agriculture, although water conservation strategies will also be necessary in deficit irrigated systems (Debaeke and Aboudrare, 
2004). In most cases, but mainly in semi-arid regions, the use efficiency of scarce water resources has been increased by promoting soil and water conservation techniques as mulching in no-till systems for reducing soil runoff and evaporation (Aboudrare et al., 2006). Tillage practices (minimum or no tillage), which include maintaining crop residues from previous harvests on the soil surfaces, are likely to help maintaining soil quality, protecting against erosion, and facilitating water infiltration (Lal et al., 2011). For instance, in Colorado, model simulations showed that up to year 2075, no-tillage should maintain higher wheat yields than conventional tillage in a wheat-fallow rotation (Ko et al., 2012). In Australia, adoption of zero tillage, stubble retention, early sowing, enhanced weed control, and perennial crops and pastures are all suggested to farmers for adapting to reduced precipitation under rainfed conditions (Howden et al., 2007; Stokes and Howden, 2010).

Nitrogen fertilizer management needs to be adjusted to increasing or decreasing yield expectations and to decreasing soil moisture. In soils containing sufficient amounts of moisture and organic matter, enhanced mineralization with increasing temperature must be accounted for (Nendel et al., 2014). However, this may not happen if soil moisture is too low or if droughts are prolonged in time with climate change. The rate and timing of $\mathrm{N}$ fertilizer application will be changed as a function of soil moisture in order to maintain the efficacy of plants to use $\mathrm{N}$ fertilizer but also to optimize crop canopy development and duration according to available transpirable water (e.g. for preventing hayingoff in cereals).

Implementation, maintenance and enhancement of agroforestry could contribute to climate change adaptation locally by maximizing the use of soil water resource (Abildtrup et al., 2006; Nguyen et al., 2013).

\subsection{Long-term adaptation of the agricultural sector}

Given the gradual change of climate in the past, farmers have adapted autonomously by successive technical adjustments to climate change and variability as previously described. However, with the large climate change anticipated by the end of this century, transformational changes (in land allocation and management, farming systems, and plant breeding) could be planned considering possible disruptions in farming systems, land use, and resulting crop productivity (Bindi and Olesen, 2011; Kates et al., 2012; Anwar et al., 2013).

Breeding for new varieties better adapted to thermal shocks (heat and cold), drought, waterlogging and higher atmospheric $\mathrm{CO}_{2}$ concentration is often suggested as the major long-term adaptation to climate change as current cultivars were selected for long with different targets (Ceccarelli et al., 2010; Boote et al., 2011; Ziska et al., 2012). For instance, sunflower varieties adapted to early planting with increased vigor should be selected to take advantage of autumn or early spring planting dates (Houmanat et al., 2016). However, breeding is often a slow process (about 10 years to develop a new crop cultivar to the point of commercial production), so it must begin well before it is expected that new cultivars will be needed (Asseng and Pannell, 2013). Uncertainty about the extent of future change is very high for rainfall, moderately high for temperature and relatively low for $\mathrm{CO}_{2}$ concentration. The impact assessment of adapted cultivars would strongly depend on the assumptions made on breeding advances (Graß et al., 2015). However, given that climatic changes are relatively slow, there is more time for annual field crops to deliver suitable outputs in time. Several public-private research consortia (e.g. AMAIZING for maize, SUNRISE for sunflower) are still running in France to identify droughttolerant materials and accelerate the creation of varieties better adapted to climate change in Europe (Debaeke et al., 2017).

Model-based tools, climate forecasting and site-specific technology should be developed to optimize, support and secure farmer's decisions. Remote sensing (drone, satellite) and precision farming could be used to increase the information on plant canopies and maximize resource-use efficiency. Adaptation could range from tactical fine-tuning to deep changes in the nature of cropping systems with downstream impacts on land use and agricultural sector activity (machinery, inputs, market). The extent of numerical agriculture and the willingness to diversify crops and varieties to increase the resilience at farm or territorial level will change deeply the socio-technical system (e.g. cooperatives, consultants, seed companies) with possible lock-ins in the adoption of innovations.

\section{Antagonisms, synergies and trade-offs between mitigation and adaptation}

In adopting adaptation options (Tab. 2), however, it is necessary to consider the multifunctional role of agriculture and the potential contribution of the agriculture sector in GHG mitigation (Pellerin et al., 2013). According to Smith and Olesen (2010), most categories of adaptation options for climate change should have positive impacts on mitigation by improving nitrogen use efficiencies and soil carbon storage (e.g. measures for reducing soil erosion, conserving soil moisture and preventing nutrient losses, adjusting $\mathrm{N}$ and water rates to actualized yield goals, diversification of crop rotations...).

For instance, conservation agriculture based on minimum soil disturbance, retention of crop residues, continuous soil covering with vegetation or organic mulch, diversified crop rotation and plurispecific stands is a way to improve carbon sequestration in soils and nutrient cycling, reduce soil degradation, secure food production (especially in smallholders farms in the tropics), and exploit opportunities when offered by longer growing seasons (Brouder and GomezMacpherson, 2014; Giller et al., 2015; Craheix et al., 2016). By reducing soil erosion and nutrient leaching, conserving soil moisture, and increasing crop biodiversity, conservation agriculture could be a pillar of climate-smart agriculture in most parts of the world. Over the past 10 years, it has been promoted among smallholder farmers in the tropics, often with disappointing results (Giller et al., 2015). First, conservation agriculture requires more labor for weed control operations (when no chemicals are used) and secondly, the competition for crop residues used for soil mulching or animal feeding is a problem in mixed crop-livestock farms in the tropics.

Similarly, agroforestry is often mentioned as a good solution for maximizing the use of soil resources (water, nitrogen) and modifying microclimate to reduce temperature 
extremes and provide shelter, while producing more biomass than single crops and then storing a larger amount of $\mathrm{C}$ in the soil-plant system. This is a promising option for smallholder farmers in Africa with well-documented yield and profitability improvements, which seems more conclusive and easier to promote than conservation agriculture (Kaczan et al., 2013).

Low input management in general is recommended to adapt crop canopy development and yield target to decreasing water resources: if properly applied, it should also reduce $\mathrm{N}_{2} \mathrm{O}$ emissions as $\mathrm{N}$ fertilizer requirement is reduced. Organic agriculture based on the use of legumes and manure as substitutes to mineral $\mathrm{N}$ fertilizers contributes to $\mathrm{GHG}$ mitigation and to adaptation to climate change: crop diversification is often the rule, soil storage capacities are generally improved in relation with increasing organic matter content and related soil stability, which increases water infiltration rate (Niggli et al., 2009; Lal et al., 2011; Kölling and ElolaCalderón, 2012). However, the debate still exists on the capability of organic and low input agriculture to feed the growing world population. From a meta-dataset of 362 published organic-conventional comparative crop yields, de Ponti et al. (2012) reported that crop yields in organic systems were on average $80 \%$ of conventional ones.

On the other hand, some mitigation measures may not be as positive for the adaptive capacity of farming systems. The contribution of legumes to reduce GHG emissions and to limit the exhaustion of fossil fuels has been proved to be very important (Jensen et al., 2012; Jeuffroy et al., 2013b; Peyrard et al.,2016). Numerous agronomic and environmental benefits of legumes have been reported (Voisin et al., 2014), their contribution to soil fertility being one of the key factors in sustaining the production of cereal crops in rainfed dry areas in developing countries and more generally in low input systems. In addition, the indeterminate growth pattern of most legumes provides plasticity to environmental stresses by allowing the development of additional flowers and then seeds when more favorable growing conditions occur (Vadez et al., 2012).

However, the restricted root development of most grain legume species may limit water and nutrient uptake, especially at late growth stages when environmental stresses are frequent. Symbiotic $\mathrm{N}_{2}$ fixation which takes place in the top soil layers is extremely susceptible to drought (Liu et al., 2011). High temperatures may affect dramatically anthesis and seed set contributing to flower abortion (Daryanto et al., 2015). Consequently, the yield of food legumes grown in arid to semiarid environments are usually variable or low due to severe heat and terminal droughts that characterize these areas. Even in wetter environments, water deficiency may still occur over a period of a few weeks, causing significant yield loss. Therefore, breeding efforts are necessary to improve the adaptation potential of legume crops to heat and water stresses concomitantly with earlier sowing dates, development of winter types, and intercropping with cereals (Cutforth et al., 2007; Vadez et al., 2012).

Sequential multiple cropping (double or relay; main and cover crops) is often advocated as effective method for increasing crop productivity while protecting soil and storing more carbon (Chataway et al., 2011; Rao et al., 2015). In regions where water is limited, more irrigation will be necessary to make possible the summer growth of double crops or the establishment of cover crops at the end of summer (Meza et al., 2008). In addition, more transpiration and possible soil water shortage are expected when extending the duration of green canopies. In some regions, one-year fallow periods will have to be maintained for storing the critical water volume for crop production in subsequent year as traditionally. However, in the dry Canadian Prairie, this system was found to be prone to wind erosion and other negative side-effects on soil health and it has been replaced with cereal / grain legume rotations (Zentner et al., 2004).

\section{Conclusions}

Through this short review, we pointed out numerous actionable mitigation and adaptation options and highlighted some trade-offs to deal with when designing multi-functional cropping systems adapted to climate-smart temperate and tropical agriculture. In most cases, adaptation and mitigation measures are not specific of either temperate or tropical agroecosystems although they may differ by their modalities in each environment.

Some adaptations options are more driven by long-term trends: firstly, with increasing temperature, planting dates have been shifted and crop durations modified using current varietal panels, then new crop species will be progressively introduced, and later, innovative varieties will be cultivated issuing from a breeding process integrating explicitly these trends (e.g. $\mathrm{CO}_{2}$, temperature, drought). Besides, diversifying crop plans and rotations and promoting multiple cropping with a range of species and varieties should be rather seen as an adaptive response to the increasing inter-annual and intra-season climatic variability.

Cropping systems based on biodiversity and sustainable soil management (e.g. agroforestry, conservation agriculture), and using less (or no) chemical inputs (organic farming) could result in a satisfying compromise between food production, adaptation and mitigation to climate change, thanks to new biological regulations that have emerged in such low-chemicals and diversified cropping systems. Indeed, as stated by Tittonell (2015), "agroecology is climate-smart". However, during the transition phase to stable agroecological systems, crop production will be probably depressed by climatic factors and uncontrolled input reduction. Therefore, crop breeding will have to propose urgently suitable cultivars for such production systems, not only water and heat resistant cultivars but also more vigorous and multiple disease-resistant ideotypes, which cover rapidly the soil for water conservation and weed suppression.

Establishing climate-smart and resilient cropping systems may involve the implementation of integrated strategies comprised of relevant sets of management practices rather than implementing specific practices one at a time. To achieve this goal, methods for designing and assessing climate-smart cropping systems (based on crop modeling, prototyping and multicriteria approaches) have to be selected and adapted to the new and projected climatic context. When testing the adaptation and mitigation solutions in the real world, farm constraints will have to be considered explicitly and decisionmaking tools will be required to put in practice such complex strategies at field and farm level. 


\section{References}

Abildtrup J, Audsley E, Fekete-Farkas M, Giupponi C, Gylling M, Rosato P, et al. 2006. Socio-economic scenario development for the assessment of climate change impacts on agricultural land use: a pairwise comparison approach. Environmental Science \& Policy 9: 101-115.

Aboudrare A, Debaeke P, Bouaziz A, Chekli H. 2006. Effects of soil tillage and fallow management on soil water storage and sunflower production in a semiarid Mediterranean climate. Agricultural Water Management 83: 183-196.

Aertsens J, De Nocker L, Gobin A. 2013. Valuing the carbon sequestration potential for European agriculture. Land Use Policy 31: 584-594.

Angers DA, Eriksen-Hamel NS. 2008. Full-inversion tillage and organic carbon distribution in soil profiles: a meta-analysis. Soil Science Society of America Journal 72: 1370-1374.

Anwar MR, Liu DE, Macadam I, Kelly G. 2013. Adapting agriculture to climate change: a review. Theoretical and Applied Climatology 113: 225-245.

Arrouays D, Balesdent J, Germon JC, Jayet PA, Soussana JF, Stengel $\mathrm{P}$ (Eds.). 2002. Contribution à la lutte contre l'effet de serre. Stocker du carbone dans les sols agricoles de France ? Expertise scientifique collective. Synthèse du rapport, Inra (France), $32 \mathrm{p}$.

Asseng S, Pannell DJ. 2013. Adapting dryland agriculture to climate change: farming implications and research and development needs in Western Australia. Climatic Change 118: 167-181.

Autret B, Mary B, Chenu C, Balabane M, Girardin C, Bertrand M, et al. 2016. Alternative arable cropping systems: A key to increase soil organic carbon storage? Results from a 16 year field experiment. Agriculture, Ecosystems \& Environment 232: 150-164.

Bindi M, Olesen JE. 2011. The responses of agriculture in Europe to climate change. Regional Environmental Change 11 (Suppl. 1): S151- S158.

Boiffin J, Benoit M, Le Bail M, Papy F, Stengel P. 2014. Agronomie, espace, territoire : travailler «pour et sur » le développement territorial, un enjeu pour l'agronomie. Cahiers Agricultures 23: 72 83. DOI: 10.1684 /agr.2014.0688.

Boote KJ, Ibrahim AMH, Lafitte R, McCulley R, Messina C, Murray $\mathrm{SC}$, et al. 2011. Position statement on crop adaptation to climate change. Crop Science 51: 2337-2343.

Bradshaw B, Dolan H, Smit B. 2004. Farm-level adaptation to climatic variability and change: crop diversification in the Canadian Prairies. Climatic Change 67: 119-141.

Brisson N, Levrault F (Eds). 2010. Climate change, agriculture and forests in France: simulations of the impacts on the main species. The Green Book of the CLIMATOR Project (2007-2010). Paris (France): Ademe.

Brisson N, Gate P, Gouache D, Charmet G, Oury FX, Huard F. 2010. Why are wheat yields stagnating in Europe? A comprehensive data analysis for France. Field Crops Research 119: 201-212.

Brouder SM, Gomez-Macpherson H. 2014. The impact of conservation agriculture on smallholder agricultural yields: A scoping review of the evidence. Agriculture, Ecosystems \& Environment 187: 11-32.

Ceccarelli S, Grando S, Maatougui M, Michael M, Slash M, Haghparast R, et al. 2010. Plant breeding and climate changes. The Journal of Agricultural Science 148: 627-637.

Challinor A, Wheeler T, Garforth C, Craufurd P, Kassam A. 2007. Assessing the vulnerability of food crop systems in Africa to climate change. Climatic Change 83: 381-399.
Chataway RG, Cooper JE, Orr WN, Cowan RT. 2011. The role of tillage, fertiliser and forage species in sustaining dairying based on crops in southern Queensland 2. Double-crop and summer solecrop systems. Animal Production Science 51: 904-919.

Chen C, Qian C, Deng A, Zhang W. 2012. Progressive and active adaptations of cropping system to climate change in Northeast China. European Journal of Agronomy 38: 94-103.

Chun JA, Shim KM, Min SH, Wang Q. 2016. Methane mitigation for flooded rice paddy systems in South Korea using a process-based model. Paddy and Water Environment 14: 123-129.

Ciais P, Sabine C, Bala G, Bopp L, Brovkin V, Canadell J, et al. 2013. Carbon and other biogeochemical cycles. In: Stocker TF, Qin D, Plattner GK, Tignor M, Allen SK, Boschung J, et al. (eds). Climate Change 2013: The Physical Science Basis Contribution of Working Group I to the Fifth Assessment Report of the Intergovernmental Panel on Climate Change. Cambridge, United Kingdom and New York. NY, USA: Cambridge University Press.

Craheix D, Angevin F, Doré T, de Tourdonnet S. 2016. Using a multicriteria assessment model to evaluate the sustainability of conservation agriculture at the cropping system level in France. European Journal of Agronomy 76: 75-86.

Cutforth HW, McGinn SM, McPhee KE, Miller PR. 2007. Adaptation of pulse crops to the changing climate of the Northern Great Plains. Agronomy Journal 99: 1684-169.

Daryanto S, Wang L, Jacinthe PA. 2015. Global synthesis of drought effects on food legume production. PloS ONE 10(6): e0127401.

Debaeke P. 2004. Scenario analysis for cereal management in waterlimited conditions by the means of a crop simulation model (STICS). Agronomie 24: 315-326.

Debaeke P, Aboudrare A. 2004. Adaptation of crop management to water-limited environments. European Journal of Agronomy 21: 433-446.

Debaeke P, Bergez JE, Leenhardt D. 2008. Perspectives agronomiques et génétiques pour limiter ou réguler la demande en eau d'irrigation. La Houille Blanche 6: 17-25.

Debaeke P, Casadebaig P, Flénet F, Langlade N. 2017. Sunflower crop and climate change: vulnerability, adaptation, and mitigation potential from case-studies in Europe. OCL - Oilseeds and fats, Crops and Lipids 24(1): D102.

Dimassi B, Cohan JP, Labreuche J, Mary B. 2013. Changes in soil carbon and nitrogen following tillage conversion in a long-term experiment in Northern France. Agriculture, Ecosystems \& Environment 169: 12-20.

Dimassi B, Mary B, Wylleman R, Labreuche J, Couture D, Piraux F, et al. 2014. Long-term effect of contrasted tillage and crop management on soil carbon dynamics during 41 years. Agriculture, Ecosystems \& Environment 188: 134-146.

Ding DY, Feng H, Zhao Y, He JQ, Zou YF, Jin JM. 2016. Modifying winter wheat sowing date as an adaptation to climate change on the Loess Plateau. Agronomy Journal 108: 53-63.

Doll, P. 2002. Impact of climate change and variability on irrigation requirements: a global perspective. Climatic Change 54: 269-293.

Donatelli M, Duveiller G, Fumagalli D, Srivastava A, Zucchini A, Angileri V, et al. 2012. Assessing agriculture vulnerabilities for the design of effective measures for adaption to climate change (AVEMAC project). European Union, Joint Research Centre. DOI: $102788 / 16181$.

Falloon P, Betts R. (2010). Climate impacts on European agriculture and water management in the context of adaptation and mitigationthe importance of an integrated approach. Science of the Total Environment 408: 5667-5687.

Food and Agriculture Organization of the United Nations (FAO). 2013. Climate-Smart Agriculture Sourcebook Rome, Italy. 
Fumoto T, Yanagihara T, Saito T, Yagi K. 2010. Assessment of the methane mitigation potentials of alternative water regimes in rice fields using a process-based biogeochemistry model. Global Change Biology 16: 1847-1859.

Gabrielle B, Bamiere L, Caldes N, De Cara S, Decocq G, Ferchaud F, et al. 2014. Paving the way for sustainable bioenergy in Europe: technological options and research avenues for large-scale biomass feedstock supply. Renewable \& Sustainable Energy Reviews 33: $11-25$.

Gianquinto G, Orsini F, Sambo P, D’Urzo MP. 2011. The use of diagnostic optical tools to assess nitrogen status and to guide fertilization of vegetables. Horttechnology 21: 287-292.

Giller KE, Andersson JA, Corbeels M, Kirkegaard J, Mortensen D, Erenstein O, et al. 2015. Beyond conservation agriculture. Frontiers in Plant Science 6: 870.

Graß R, Thies B, Kersebaum KC, Wachendorf M. 2015. Simulating dry matter yield of two cropping systems with the simulation model HERMES to evaluate impact of future climate change. European Journal of Agronomy 70: 1-10.

Gregory PJ, Johnson SN, Newton AC, Ingram JSI. 2009. Integrating pests and pathogens into the climate change/food security debate. Journal of Experimental Botany 60: 2827-2838.

Houmanat K, El Fechtali M, Mazouz H, Nabloussi A. 2016. Assessment of sunflower germplasm selected under autumn planting conditions. In: Proceedings of the 19th International Sunflower Conference. Turkey: Edirne, pp. 286-293.

Howden SM, Soussana JF, Tubiello FN, Chhetri N, Dunlop M, Meinke H. 2007. Adapting agriculture to climate change. In: Proceedings of the National Academy of Sciences of the United States of America 104(50): 19691-19696.

Iglesias A, Quiroga S, Moneo M, Garrote L. 2012. From climate change impacts to the development of adaptation strategies: challenges for agriculture in Europe. Climatic Change 112: 143-168.

Jalota SK, Kaur H, Ray SS, Tripathi SR, Vashisht BB, Bal SK. 2012. Mitigating future climate change effects by shifting planting dates of crops in rice-wheat cropping system. Regional Environmental Change 12: 913-922.

Jensen ES, Peoples MB, Boddey RM, Gresshoff PM, HauggaardNielsen H, Alves BJR, et al. 2012. Legumes for mitigation of climate change and the provision of feedstock for biofuels and biorefineries. A review. Agronomy for Sustainable Development 32: 329-364.

Jeuffroy MH, Gate P, Machet JM, Recous S. 2013a Nitrogen management in arable crops: can available knowledge and tools reconcile agronomic and environmental needs? Cahiers Agricultures 22: 249-257. DOI: 10.1684/agr.2013.0639

Jeuffroy MH, Baranger E, Carrouée B, de Chezelles E, Gosme M, Henault C, et al. 2013b. Nitrous oxide emissions from crop rotations including wheat, oilseed rape and dry peas. Biogeosciences 10: 1787-1797.

Justes E, Beaudoin N, Bertuzzi P, Charles R, Constantin J, Dürr C, et al. 2012. Réduire les fuites de nitrate au moyen de cultures intermédiaires : conséquences sur les bilans d'eau et d'azote, autres services écosystémiques. Synthèse du rapport d'étude. France: Inra, $60 \mathrm{p}$.

Kaczan D, Arslan A, Lipper L. 2013. Climate-smart agriculture? A review of current practice of agroforestry and conservation agriculture in Malawi and Zambia. ESA Working Paper No. 13-07. Roma (Italy): FAO.

Kates RW, Travis WR, Wilbanks TJ. 2012. Transformational adaptation when incremental adaptations to climate change are insufficient. In: Proceedings of the National Academy of Sciences of the United States of America 109(19): 7156-7161.
Khosa MK, Sidhu BS, Benbi DK. 2011. Methane emission from rice fields in relation to management of irrigation water. Journal of Environmental Biology 32: 169-172.

Ko J, Ahuja LR, Saseendran SA, Green TR, Ma L, Nielsen DC, et al. 2012. Climate change impacts on dryland cropping systems in the Central Great Plains, USA. Climatic Change 111: 445-472.

Kölling A, Elola-Calderón T (eds.). 2012. Organic agriculture: a strategy for climate change adaptation. Brüssels (Belgium): IFOAM EU Group.

Lal R. 2011. Sequestering carbon in soils of agro-ecosystems. Food Policy 36: S33- S39.

Lal R, Delgado JA, Groffman PM, Millar N, Dell C, Rotz A. 2011. Management to mitigate and adapt to climate change. Journal of Soil Water Conservation 66: 276-285.

Laux P, Jäckel G, Tingem RM, Kunstmann H. 2010. Impact of climate change on agricultural productivity under rainfed conditions in Cameroon. A method to improve attainable crop yields by planting date adaptations. Agricultural and Forest Meteorology 150: 1258-1271.

Lemaire G, Jeuffroy MH, Gastal F. 2008. Diagnosis tool for plant and crop $\mathrm{N}$ status in vegetative stage theory and practices for crop N management. European Journal of Agronomy 28: 614-624.

Linquist BA, Adviento-Borbe MA, Pittelkow CM, van Kessel C, van Groenigen KJ. 2012. Fertilizer management practices and greenhouse gas emissions from rice systems: a quantitative review and analysis. Field Crops Research 135: 10-21.

Lipper L, Thornton PK, Campbell B, Baedeker T, Braimoh A, Bwalya M, et al. 2014. Climate smart agriculture for food security. Nature Climate Change 4: 1068-1072.

Liu Y, Wu L, Baddeley JA, Watson CA. 2011. Models of biological nitrogen fixation of legumes. A review. Agronomy for Sustainable Development 31: 155-172.

Majumdar D. 2003. Methane and nitrous oxide emission from irrigated rice fields: proposed mitigation strategies. Current Science 84: 1317-1326.

Meza FJ, Silva D, Vigil H. 2008. Climate change impacts on irrigated maize in Mediterranean climates: evaluation of double cropping as an emerging adaptation alternative. Agricultural Systems 98: 21-30.

Moradi R, Koocheki A, Mahallati MN, Mansoori H. 2013. Adaptation strategies for maize cultivation under climate change in Iran: irrigation and planting date management. Mitigation and Adaptation Strategies for Global Change 18: 265-284.

Moriondo M, Bindi M, Kundzewicz ZW, Szwed M, Chorynski A, Matczak P, et al. 2010. Impact and adaptation opportunities for European agriculture in response to climatic change and variability. Mitigation and Adaptation Strategies for Global Change 15: 657-679.

Nendel C, Kersebaum KC, Mirschel W, Wenkel KO. 2014. Testing farm management options as climate change adaptation strategies using the MONICA model. European Journal of Agronomy 52: 47-56.

Nguyen Q, Hoang MH, Öborn I, van Noordwijk M. 2013. Multipurpose agroforestry as a climate change resiliency option for farmers: an example of local adaptation in Vietnam. Climatic Change 117: 241-257.

Niggli U, Fließbach A, Hepperly P, Scialabba N. 2009. Low greenhouse gas agriculture: mitigation and adaptation potential of sustainable farming systems. Rome, Italy: FAO.

Olesen JE, Carter TR, Diaz-Ambrona CH, Fronzek S, Heidmann T, Hickler T, et al. 2007. Uncertainties in projected impacts of climate change on European agriculture and terrestrial ecosystems based 
on scenarios from regional climate models. Climatic Change 81: 123-143.

Olesen JE, Trnka M, Kersebaum KC, Skjelvag A, Seguin B, PeltonenSainio P, et al. 2011. Impacts and adaptation of European crop production systems to climate change. European Journal of Agronomy 34: 96-112.

Pellerin S, Bamière L, Angers D, Béline F, Benoît M, Butault J-P., et al. 2013. How can French agriculture contribute to reducing greenhouse gas emissions? Abatement potential and cost of ten technical measures. Synopsis of the study report. France: Inra, $92 \mathrm{p}$.

Pellerin S, Bamière L, Angers D, Béline F, Benoît M, Butault J-P., et al. 2014. Quels leviers techniques pour l'atténuation des émissions de gaz à effet de serre d'origine agricole ? Innovations Agronomiques 37: 1-10

Peyrard C, Mary B, Perrin P, Véricel G, Gréhan E, Justes E, et al. 2016. $\mathrm{N}_{2} \mathrm{O}$ emissions of low input cropping systems as affected by legume and cover crops use. Agriculture, Ecosystems \& Environment 224: 145-156.

de Ponti T, Rijk B, van Ittersum MK. 2012. The crop yield gap between organic and conventional agriculture. Agricultural Systems 108: 1-9.

Porter JR, Xie L, Challinor V, Cochrane K, Howden SM, Iqbal MM, et al. 2014. Food security and food production systems. In: Climate change 2014: impacts, adaptation, and vulnerability. Cambridge, UK \& New York, USA: Cambridge University Press, pp. 485-533.

Powlson DS, Stirling CM, Jat ML, Gerard BG, Palm CA, Sanchez PA, et al. 2014. Limited potential of no-till agriculture for climate change mitigation. Nature Climate Change 4: 678683.

Rao VN, Meinke H, Craufurd PQ, Parsons D, Kropff MJ, Niels PR, et al. 2015. Strategic double cropping on vertisols: a viable rainfed cropping option in the Indian SAT to increase productivity and reduce risk. European Journal of Agronomy 62: 26-37.

Ravier C, Jeuffroy M-H., Meynard J-M. 2016. Mismatch between a science-based decision tool and its use: The case of the balancesheet method for nitrogen fertilization in France. NJAS Wageningen Journal of Life Sciences 79: 31-40.

Rochette P. 2008. No-till only increases $\mathrm{N}_{2} \mathrm{O}$ emissions in poorlyaerated soils. Soil \& Tillage Research 101: 97-100.

Rochette P, Janzen HH. 2005. Towards a revised coefficient for estimating $\mathrm{N}_{2} \mathrm{O}$ emissions from legumes. Nutrient Cycling in Agroecosystems 73: 171-179.

Rosenzweig C, Tubiello N. 2007. Adaptation and mitigation strategies in agriculture: an analysis of potential synergies. Mitigation and Adaptation Strategies for Global Change 12: $855-873$.

Sarr B. 2012. Present and future climate change in the semi-arid region of West Africa: a crucial input for practical adaptation in agriculture. Atmospheric Science Letters 13: 108-112.

Seifert CA, Lobell DB. 2015. Response of double cropping suitability to climate change in the United States. Environmental Research Letters 10: 024002.

Smit B, Skinner MW. 2002. Adaptation options in agriculture to climate change: a typology. Mitigation and Adaptation Strategies for Global Change 7: 85-114.

Smith P, Bustamante M, Ahammad H, Clark H, Dong H, Elsiddig EA, et al. 2014. Agriculture, forestry and other land use (AFOLU). In: Edenhofer O, Pichs-Madruga R, Sokona Y, Farahani E, Kadner S, Seyboth K, et al. (eds). Climate change 2014: mitigation of climate change contribution of working group III to the fifth assessment report of the intergovernmental panel on climate change. Cambridge, United Kingdom and New York, NY, USA: Cambridge University Press.

Smith P, Olesen JE. 2010. Synergies between the mitigation of, and adaptation to, climate change in agriculture. The Journal of Agricultural Science 148: 543-552.

Soriano MA, Orgaz F, Villalobos FJ, Fereres E. 2004. Efficiency of water use of early plantings of sunflower. European Journal of Agronomy 21: 465-476.

Stokes C, Howden M (eds.). 2010. Adapting agriculture to climate change. Preparing Australian agriculture, forestry and fisheries for the future CSIRO Publishing, $296 \mathrm{p}$.

Supit I, CA van Diepen, AJW de Wit, J Wolf, P Kabat, B Baruth, et al. 2012. Assessing climate change effects on European crop yields using the crop growth monitoring system and a weather generator. Agricultural and Forest Meteorology 164: 96-111.

Tittonell P. 2015. Agroecology is climate smart. In: Climate Smart Agriculture 2015: Global Science Conference 3, Montpellier (France), p. 19

Torquebiau E. (ed). 2015. Changement climatique et agricultures du monde. Paris: Éditions Quae, 328 p.

Towprayoon S, Smakgahn K, Poonkaew S. 2005. Mitigation of methane and nitrous oxide emissions from drained irrigated rice fields. Chemosphere 59: 1547-1556.

Tuck G, Glendining MJ, Smith P, House JI, Wattenbach M. 2006. The potential distribution of bioenergy crops in Europe under present and future climate. Biomass \& Bioenergy 30: 183-197.

Vadez V, Berger JD, Warkentin T, Asseng S, Ratnakumar P, Rao KPC, et al. 2012. Adaptation of grain legumes to climate change: a review. Agronomy for Sustainable Development 32: 31-44.

van Ittersum MK, Howden SM, Asseng S. 2003. Sensitivity of productivity and deep drainage of wheat cropping systems in a Mediterranean environment to changes in $\mathrm{CO}_{2}$, temperature and precipitation. Agriculture, Ecosystems \& Environment 97: 255-273.

Virto I, Barre P, Burlot A, Chenu C. 2012. Carbon input differences as the main factor explaining the variability in soil organic $\mathrm{C}$ storage in no-tilled compared to inversion tilled agrosystems. Biogeochemistry 108: 17-26.

Voisin AS, Gueguen J, Huyghe C, Jeuffroy MH, Magrini MB, Meynard JM, et al. 2014. Legumes for feed, food, biomaterials and bioenergy in Europe: a review. Agronomy for Sustainable Development 34: 361-380.

Waha K, Müller C, Bondeau A, Dietrich JP, Kurukulasuriya P, Heinke J, et al. 2013. Adaptation to climate change through the choice of cropping system and sowing date in sub-Saharan Africa. Global Environmental Change 23: 130-143.

Wang J, Wang E, Yang X, Zhang F, Yin H. 2012. Increased yield potential of wheat-maize cropping system in the North China Plain by climate change adaptation. Climatic Change 113: 825 840.

Waongo M, Laux P, Kunstmann H. 2015. Adaptation to climate change: the impacts of optimized planting dates on attainable maize yields under rainfed conditions in Burkina Faso. Agricultural and Forest Meteorology 205: 23-39.

Xie BH, Zheng XH, Zhou ZX, Gu JX, Zhu B, Chen X, et al. 2010. Effects of nitrogen fertilizer on $\mathrm{CH}_{4}$ emission from rice fields: multi-site field observations. Plant and Soil 326: 393-401.

Yan XY, Akiyama H, Yagi K, Akimoto H. 2009. Global estimations of the inventory and mitigation potential of methane emissions from rice cultivation conducted using the 2006 Intergovernmental Panel on Climate Change Guidelines. Global Biogeochemical Cycles 23: GB2002. 
Zentner RP, Campbell CA, Biederbeck VO, Selles F, Lemke R, Jefferson PG, et al. 2004. Long-term assessment of management of an annual legume green manure crop for fallow replacement in the Brown soil zone. Canadian Journal of Plant Science 84: $11-22$.

Zhao G, Webber H, Hoffmann H, Wolf J, Siebert S, Ewert F. 2015. The implication of irrigation in climate change impact assessment: a European-wide study. Global Change Biology 21: 4031-4048.
Ziadi N, Belanger G, Claessens A, Lefebvre L, Tremblay N, Cambouris AN, et al. 2010. Plant-based diagnostic tools for evaluating wheat nitrogen status. Crop Science 50: 2580-2590.

Ziska LH, Bunce JA, Shimono H, Gealy DR, Baker JT, Newton PCD, et al. 2012. Food security and climate change: on the potential to adapt global crop production by active selection to rising atmospheric carbon dioxide. In: Proceedings of the Royal Society B: Biological Sciences 279(1745): 4097-4105.

Cite this article as: Debaeke P, Pellerin S, Scopel E. 2017. Climate-smart cropping systems for temperate and tropical agriculture: mitigation, adaptation and trade-offs. Cah. Agric. 26: 34002. 